\title{
Advances in the detection and quantification of candidate and established biomarkers in heart failure
}

\section{Progrese în detectarea şi cuantificarea biomarkerilor potențiali şi uzuali în insuficiența cardiacă}

\author{
Cristina Pop ${ }^{1}$, Gianina C. Crişan ${ }^{2 *}$, Felicia Loghin ${ }^{3}$, Cristina I. Mogoşan ${ }^{1}$ \\ "Iuliu Hațieganu" University of Medicine and Pharmacy Cluj-Napoca \\ 1. Department of Pharmacology, Physiology and Pathophysiology, 2. Department of Botanic and \\ Molecular Biology, 3. Department of Toxicology
}

\begin{abstract}
Heart failure (HF) is a common condition, especially in older patients. Considering the increase of life expectancy the total number of HF patients is expected to grow in the future, which makes HF an important focus of research. New high-throughput techniques, such as the "omics" (genomics, transcriptomics, metabolomics) have brought new insight into disease pathophysiology, facilitating the discovery of an impressive number of candidate biomarkers. In this review we consider different perspectives on the evaluation and clinical potential of biomarkers in heart failure as their usefulness in clinical settings is constantly being evaluated in order to bring them closer to the point-of-care. In addition, we examine recent advances in the methods of detection and quantification of biomarkers.
\end{abstract}

Keywords: heart failure, biomarker, diagnostic, prognostic, multi-marker strategy.

\section{Rezumat}

Insuficiența cardiacă este o afecțiune cu o prevalentă ridicată, în special în rândul pacienților vârstnici. $P e$ viitor, se preconizează creşterea numărului de pacienți cu insuficiență cardiacă, luând în considerare creşterea speranței de viaţă, ceea ce sporeşte interesul ştiințific pentru această patologie. Noile tehnologii „omice” cum ar fi genomica, proteomica sau metabolomica au contribuit la elucidarea fiziopatologiei insuficienței cardiace prin furnizarea unui număr impresionant de potențiali biomarkeri. In acest review vom prezenta diferiții biomarkeri candidați şi uzuali pentru insuficiența cardiacă şi utilitatea lor clinică, precum şi progresele făcute pentru creşterea sensibilității, selectivității şi reproductibilității metodelor lor de detecție şi cuantificare.

Cuvinte cheie: insuficiență cardiacă, biomarker, diagnostic, prognostic, strategie multi-marker.

Received: 13 $3^{\text {th }}$ April 2013; Accepted: $5^{\text {th }}$ September 2013; Published: $9^{\text {th }}$ September 2013.

*Corresponding author: Gianina Crişan, 12 Ion Creangă Street, Cluj-Napoca, Cluj, Romania.

Tel. 0264595454, E-mail: gcrisan@umfcluj.ro 


\section{Introduction}

Heart failure (HF) is the result of a wide range of cardiovascular disorders that influence negatively the heart's property to fill or to pump blood. Due to its multiple etiologies, HF is a common condition, affecting approximately $1-2 \%$ of the population in developed countries, with a prevalence of more than $10 \%$ within the 70 -years-or-older agegroup (1). Considering the increase of life expectancy and the reduction of age-adjusted mortality through disease management, the total number of HF patients is expected to grow in the future, which makes HF an important focus of research.

New high-throughput techniques, such as the "omics" (genomics, transcriptomics, metabolomics) have brought new insight into disease pathophysiology. The introduction of mass spectrometry in the analysis of proteins has opened the door to a plethora of candidate biomarkers for HF.

Through the process of validation, performed by multiple reactions monitoring (MRM) or antibody assays, the number of biomarkers decreases. Proteins are then further subjected to MRM or enzyme-linked immunosorbent assays

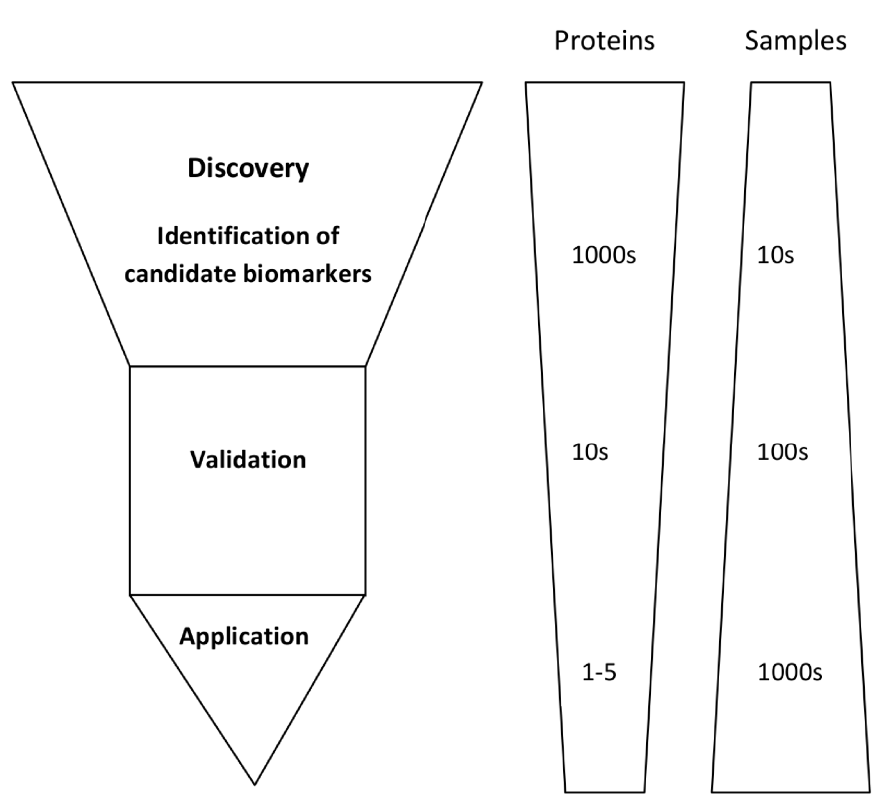

Figure 1. Stages of biomarker development.
(ELISA) to test their applicability in clinical trials (5). Table I shows some of the important criteria in the development of a biomarker in HF, in order to possess clinical utility.

Biomarkers in HF are classified according to the pathologic processes in which they may be involved, such as inflammation processes, oxidative stress, extracellular matrix remodeling, hypertrophy, fibrosis, neurohormonal activation, myocyte injury, myocyte stress or even apoptosis $(4,7,8)$.

HF biomarkers can have cardiac origin and effect, whereas others are the markers of processes that indirectly affect the heart. Many HF biomarkers provide information regarding pathologic processes associated with HF and thus have the potential to be targets of future therapies. Table II shows examples of candidate biomarkers in HF.

\section{Biomarkers of myocyte stress and apop- tosis in $\mathrm{HF}$}

The natriuretic peptides, brain natriuretic peptide (BNP) and its amino-terminal fragment (NT-proBNP), are the most studied HF biomarkers. Currently, they are the "gold standard" biomarkers for HF. They can be used in diagnosis/exclusion, prognosis and management of HF. All the major societies such as the European Society of Cardiology, the American College of Cardiology and the American Heart Association recommend their clinical use in their guidelines (1).

A cutoff value for BNP or NTproBNP of $100 \mathrm{pg} / \mathrm{mL}$ has a high specificity and sensitivity for HF (9). Other pathologies such as obesity, renal failure, anemia, stroke, pulmonary heart disease, cardiotoxic drugs can increase BNP or NT-proBNP values (7). Table III shows examples of findings of major studies that evaluated the clinical use of BNP and NTproBNP in HF. Automated immunoassays have been developed by many companies 
Table I. Criteria for new HF biomarkers.

\begin{tabular}{|c|c|}
\hline Attributes of a HF biomarker & Reference \\
\hline $\begin{array}{l}\text { 1.It is easily and quickly measured, at a reasonable price } \\
\text { 2.Has a strong correlation to HF } \\
\text { 3.Enables patient management (early detection of disease, diagnosis, risk stratification, } \\
\text { therapeutic intervention, monitoring) }\end{array}$ & $\begin{array}{l}\text { Morrow and de } \\
\text { Lemos (2). }\end{array}$ \\
\hline $\begin{array}{l}\text { 1.Confirms or excludes the diagnosis of HF and enables risk stratification of patients with } \\
\text { HF } \\
\text { 2.Can be used for screening for cardiac dysfunction } \\
\text { 3.Can guide the management of HF }\end{array}$ & Tang et al (3). \\
\hline $\begin{array}{l}\text { 1.It should be the result of an exhaustive and up-to-date evaluation process } \\
\text { 2.It should be easily and shortly quantified, with high accuracy and should have known } \\
\text { biological variation } \\
\text { 3. Can provide information regarding HF pathophysiology that can help determine diag- } \\
\text { nosis, prognosis, progression or management of HF } \\
\text { 4.It must offer new clinically useful information to enable further decision making }\end{array}$ & $\begin{array}{l}\text { Van Kimmenade } \\
\text { and Januzzi (4). }\end{array}$ \\
\hline
\end{tabular}

and their utility is constantly tested $(10,11)$. New, simpler, cost-effective methods for BNP detection such as the immunosensors are being tested as candidates for the detection of NTproBNP. They detect NT-proBNP in serum such as the regeneration-free immunosensor with novel Fab fragment monoclonal antibodies that detects NT-proBNP from 0.04 to $2.5 \mathrm{ng} / \mathrm{ml}$ with a limit of $0.03 \mathrm{ng} / \mathrm{ml}$ (12) or in whole blood such as the combination of a microfluidic system with an immunoassay based on an electrochemical immunosensor with magnetic nanoparticles, biotin-avidin system (BAS) and fragment antigen binding (Fab) antibodies (13) or the electrochemical immunosensor based on the nanostructural gold and carbon nanotubes composite, gold nanochains (AuNCs) and horseradish peroxidase (HRP) complex labeled secondary antibodies (AuNCs-HRP-Ab(2)) (14).

An increase of the A-type natriuretic peptide (ANP) and adrenomedullin (ADM) concentrations was associated with HF and low left ventricular ejection fraction (LVEF) $(4,8)$. The midreagional proADM (MR-proADM) and proANP (MR-proANP) are the more stable fragments of ANP and ADM; they have a longer half life and thus are easier to measure. The BACH trial (Biomarkers in Acute Heart Failure) has underlined their clinical utility in the diagnosis (MRproANP $\geq 120 \mathrm{pg} / \mathrm{mL}$ is associated with HF) and prognosis (MR-proADM values predict 90-days survival with an accuracy of $73 \%$ ) of HF (20). It has been suggested that both MR-proADM and MR-proANP may be useful in obese patients or in patients with renal failure, where BNP or NTproBNP are less accurate (4). Both proADM and proANP can be detected by sandwich immunoluminometric assay using two specific polyclonal antibodies for the amino acids 45-92 of proADM and 1-98 of pro ANP, respectively $(21,22)$.

ST2 is an inflammatory cytokine, member of the interleukin (IL-1) receptor family. ST2 is thought to be involved in modifying immunologic processes through its soluble (sST2) and membrane-bound (ST2L) forms, produced during myocardial strain (23). The physiologic ligand for ST2 is IL-33, which binds to ST2L and produces beneficial effects such as antihypertrophic, antifibrotic and antiapoptotic effects, but when it binds to sST2, all of its effects are neutralized (24). High levels of sST2 can be correlated to ventricular remodeling and disease 
Table II. Biomarkers used in Heart Failure and their clinical relevance $(4,8)$

\begin{tabular}{|c|c|c|c|c|c|}
\hline $\begin{array}{l}\text { Pathologic } \\
\text { processes }\end{array}$ & Biomarkers & $\begin{array}{l}\text { Prognostic } \\
\text { value }\end{array}$ & $\begin{array}{l}\text { Diagnostic } \\
\text { value }\end{array}$ & $\begin{array}{l}\text { Cardiac } \\
\text { origin }\end{array}$ & $\begin{array}{c}\text { Potential } \\
\text { targets of } \\
\text { therapy }\end{array}$ \\
\hline \multirow{7}{*}{ Inflammation } & C-reactive protein & + & Risk & - & - \\
\hline & Tumor necrosis factor $\alpha$ & + & Risk & - & - \\
\hline & Fas (APO-1) & + & Risk & - & - \\
\hline & Interleukins $1,6,18$ & + & Risk & - & - \\
\hline & Pentraxin-3 & + & Risk & - & - \\
\hline & Adiponectin & + & Risk & - & - \\
\hline & Osteoprotegerin & + & Risk & - & - \\
\hline \multirow{5}{*}{$\begin{array}{l}\text { Oxidative } \\
\text { stress }\end{array}$} & Oxidized low-density lipoproteins & + & - & - & + \\
\hline & Myeloperoxidase & + & - & - & + \\
\hline & Urinary biopyrrins & + & - & - & + \\
\hline & Urinary and plasma isoprostanes & + & - & - & + \\
\hline & Plasma malondialdehyde & + & - & - & + \\
\hline \multirow{3}{*}{$\begin{array}{l}\text { Extracellular } \\
\text { matrix remod- } \\
\text { elling }\end{array}$} & Matrix metalloproteinases (MMP) & + & - & + & + \\
\hline & $\begin{array}{l}\text { Tissue inhibitors of metalloproteinases (TIMP) } \\
\text { Collagen propeptides }\end{array}$ & + & - & + & + \\
\hline & Propeptide procollagen type I & + & - & + & + \\
\hline \multirow[t]{2}{*}{ Hypertrophy } & Plasma procollagen type III & + & - & + & + \\
\hline & Type I collagen telopeptide & + & - & + & + \\
\hline Fibrosis & Galectin 3 & + & - & + & - \\
\hline \multirow{7}{*}{$\begin{array}{l}\text { Neuro-hor- } \\
\text { monal activa- } \\
\text { tion }\end{array}$} & Norepinephrine & + & - & - & + \\
\hline & Renin & + & - & - & + \\
\hline & Angiotensin II & + & - & - & + \\
\hline & Aldosterone & + & - & - & + \\
\hline & Arginine vasopressin & + & - & - & + \\
\hline & Endothelin & + & - & - & + \\
\hline & Chromogranin A & + & - & - & + \\
\hline \multirow{4}{*}{$\begin{array}{l}\text { Myocyte in- } \\
\text { jury }\end{array}$} & Cardiac-specific troponins I and T & + & + & + & + \\
\hline & Myosin light-chain kinase I & - & Risk & + & + \\
\hline & Heart-type fatty acid protein & - & Risk & + & + \\
\hline & Creatine kinase $\mathrm{MB}$ fraction & - & Risk & + & + \\
\hline \multirow{4}{*}{ Myocyte stress } & Brain natriuretic peptide & + & + & + & + \\
\hline & N-terminal pro-brain natriuretic peptide & + & + & + & + \\
\hline & Midregion fragment of proadrenomedullin & + & + & + & + \\
\hline & ST2 & + & + & + & + \\
\hline Apoptosis & Growth differentiation factor-15 (GDF-15) & + & - & + & - \\
\hline
\end{tabular}

severity in HF. Together with natriuretic peptides and highly sensitive troponins, ST2 has a powerful prognostic value (25). Presage ST2 Assay has been approved by the Food and Drug Administration as a novel high-sensitivity imunoassay for the measurement of soluble ST2 in human plasma and it is established as a linear and stable method of detection $(26,27)$.

Growth differentiation factor 15 (GDF15 ) is a member of the transforming growth fac- tor- $\beta$ cytokine superfamily with high hopes of becoming an important biomarker in HF. It is involved in cell differentiation and tissue repair (28). A novel method of detection for GDF-15 is the microparticle-based solid-phase proximity ligation assay which has been tested against the traditional sandwich ELISA and was found to be superior (29). GDF-15 levels are high (>1200 ng/L) in acute myocardial infarction and $\mathrm{HF}$ in response to cardiac ischemia and pressure overload. GDF- 
Table III. Findings of major studies that evaluated BNP and NT-proBNP

\begin{tabular}{|c|c|c|}
\hline Study & Findings & Year \\
\hline $\begin{array}{l}\text { Breathing Not Prop- } \\
\text { erly Study (9). }\end{array}$ & $\begin{array}{l}\text { BNP had a sensitivity of } 90 \% \text { and a specificity of } 74 \% \text { for accurately diag- } \\
\text { nosing HF at a cutoff value of } 100 \mathrm{pg} / \mathrm{mL} \text {. }\end{array}$ & $\begin{array}{l}1999- \\
2000\end{array}$ \\
\hline ADHERE Study (15). & $\begin{array}{l}\text { There was a linear relationship between increasing admission BNP values } \\
\text { and increasing in-hospital mortality. }\end{array}$ & 2007 \\
\hline $\begin{array}{l}\text { Italian RED Study } \\
\text { (16). }\end{array}$ & $\begin{array}{l}\text { Assessment of BNP values at admission, at 24hours after admission and at } \\
\text { discharge had a great prognostic value for future cardiovascular events, in- } \\
\text { dependent of left ventricular ejection fraction (LVEF). }\end{array}$ & 2010 \\
\hline PRIDE Study (17). & $\begin{array}{l}\text { NT-proBNP testing alone was superior to clinical judgment alone for the di- } \\
\text { agnosis of acute congestive HF. }\end{array}$ & 2005 \\
\hline ICON Study (18). & $\begin{array}{l}\text { Clear established correlation between symptom severity and NT-proBNP } \\
\text { concentrations. An adjustment of NT-proBNP cutoff values according to age } \\
\text { must be made: }<50 \text { years, NT-proBNP } \geq 450 \mathrm{pg} / \mathrm{mL} ; 50-75 \text { years, NT- } \\
\text { proBNP } \geq 900 \mathrm{pg} / \mathrm{mL} ;>75 \text { years, NT-proBNP } \geq 1800 \mathrm{pg} / \mathrm{mL} \text {. }\end{array}$ & 2006 \\
\hline $\begin{array}{l}\text { IMPROVE CHF } \\
\text { Study (19). }\end{array}$ & $\begin{array}{l}\text { Adding NT-proBNP to clinical judgment reduced the duration of ED visit } \\
\text { by } 21 \% \text {, the number of patients rehospitalized over } 60 \text { days by } 35 \% \text {, and di- } \\
\text { rect medical costs of all medical services. }\end{array}$ & 2007 \\
\hline
\end{tabular}

15 can be used both as a prognostic and diagnostic biomarker for $\mathrm{HF}$ as it can help predict allcause mortality and identify patients with HF and preserved ejection fraction $(30,31)$.

\section{Biomarkers of inflammation in $\mathrm{HF}$}

The cytokine hypothesis of HF states that cardiac injury, for example ischemia, can trigger stress responses such as liberation of proinflammatory cytokines like tumor necrosis factor (TNF- $\alpha$ ), IL-1, IL-6 and IL-18. The expression of such cytokines affects ventricular function and facilitates the installation of HF (32).

$T N F-\alpha$ measurement can have a prognostic value in $\mathrm{HF}$ patients but can also predict the development of HF in asymptomatic patients (33). Sandwich ELISA using a well plate is a common procedure, but it is considered time-consuming. A recent study shows the advantages of performing sandwich ELISA on a microchip of cyclic olefin copolymer with 4 straight microchannels for the detection of IL-6 or TNF- $\alpha$ (34). Using a magnetic bead surface coverage assay, Tekin et al have detected attomolar quantities of TNF- $\alpha$ (35).
$C$-reactive protein $(\mathrm{CRP})$ has been associated with HF and cardiovascular risk in many studies, but lacks specificity to heart disease (36). It is believed that CRP may have protective effects but also negative effects in HF, such as up-regulation of TNF- $\alpha$ and IL-6 (37). Recently, a battery of aptamers has been patented for the detection and measurement of CRP. They represent a more accurate and sensitive method of detection than the traditional antibodies (38).

Pentraxin 3 (PTX3) has been shown to have prognostic value in patients with HF (39). PTX3, TNF- $\alpha$ and IL- 6 were found to be significantly elevated in patients with $\mathrm{HF}$ and preserved ejection fraction (39). Novel detection methods for PTX3 use high sensitive plasma ELISA assay system with monoclonal antibodies, which have a limit of detection of 0,1 $\mathrm{ng} / \mathrm{mL}$, a significantly greater sensitivity that the commercially available kits (40).

Osteoprotegerin (OPG) is a member of the tumor necrosis factor receptor superfamily has been associated with ventricular dysfunction. OPG can predict survival after myocardial infarction in HF patients (8). Increased serum 
OPG levels have been found in ischemic cardiomyopathy HF patients (41).

\section{Biomarkers of oxidative stress in HF}

Markers of oxidative stress, such as myeloperoxydases (MPOs) have demonstrated positive correlation with New York Heart Association (NYHA) functional class and diastolic dysfunction (42). MPO values $>99 \mathrm{pmol} / \mathrm{L}$, together with BNP have shown an increased prognostic value than BNP alone (43). MPO can be detected by cytochemistry, flow cytometry and immunohistochemistry, but the results of one study show the importance of using more than one method of detection, for higher accuracy (44).

\section{Biomarkers of extracellular-matrix re- modeling in $\mathrm{HF}$}

Remodeling of the ventricles is an important process in the progression of HF. An imbalance between matrix metalloproteinases (MMPs) and tissue inhibitors of metalloproteinases (TIMPs) leads to modifications of the extracellular matrix with further modifications of the size and shape of myocytes (8). There are at least 25 MMPs described in literature. Of all the MMPs so far only MMP2, MMP3, MMP7 and MMP9 have been linked to HF (45). They are zinc-containing endopeptidases. They degrade proteins by cleavage of peptide bonds and can be detected by zymography, while TIMP1 (tissue inhibitor of MMP1) can be detected by reverse zymography (46). TIMP1 has been found to predict all-cause mortality in chronic HF patients (47).

Galectin-3 (GAL-3) is secreted by activated macrophages and stimulates cardiac fibrosis by stimulation of collagen I deposition and irreversible cross-linking in myocytes. GAL-3 may be an indicator of cardiac remodeling and fibrosis in HF (48). Quantitative proteomic analysis employing isobaric labeling (iTRAQ - isobaric tag for relative and absolute quantitation) has been used for the detection of cardiovascular biomarkers in pregnant women, among which GAL-3 (49). Park et al used d(+)-Galactose-conjugated single-walled carbon nanotubes as biosensors and succeeded in enhancing the sensitivity for GAL-3 (50).

\section{Biomarkers of neurohormonal activation in $\mathbf{H F}$}

It is well known that in HF there is an activation of compensatory mechanisms such as the sympathetic nervous system and the reninangiotensin-aldosterone system (51). The utility of neurohormones as diagnostic or prognostic tools in HF is questionable as therapeutic agents such as beta-blockers, angiotensin converting enzyme inhibitors (ACEI), aldosterone receptors blockers (ARBs) particularly target them (52). Nevertheless, there are some markers of neurohormonal activation that have proven diagnostic or prognostic utility.

Endothelin-1 (ET-1) is considered a marker of sympathetic activation but it is not specific to HF (53). ET-1 has been measured and characterized by Laricchia-Robbio et al by using a surface plasmon resonance-based biosensor and ELISA (54). However, ET-1 is difficult to measure because of its instability, and its tendency to bind to receptors and plasma proteins. The stable surrogate of ET-1, C-terminal pro-endothelin-1 (CT-proET1) has also been positively correlated with the risk of cardiac death or heart failure (55). Papassotiriou et al have reported a robust method of indirectly measuring ET-1 by determining CT-proET-1. CT-proET-1 has been measured using a sandwich immunoluminometric assay with two polyclonal antibodies for amino acids (AA) 168-212 of pre-proET-1 (56).

Arginine vasopressin $(A V P)$ is released from the hypothalamus in states such as hypovolemia or hyponatremia. Its levels are high in HF, but as it has a very short half life, AVP is difficult to analyze. Thomas et al developed a liquid chromatography coupled to quadrupole high resolution 
Table IV. Examples of multimarkers panels for $\mathrm{HF}$

\begin{tabular}{|c|c|c|}
\hline Markers & Findings & Ref. \\
\hline $\begin{array}{l}\text { NT-proBNP, troponin I, } \\
\text { CRP, cystatin C }\end{array}$ & $\begin{array}{l}\text { Improvement of risk stratification for death from cardiovascular } \\
\text { causes among elderly men. }\end{array}$ & $\begin{array}{l}\text { Zethelius et al } \\
\text { (66). }\end{array}$ \\
\hline NT-proBNP, CRP, MPO & $\begin{array}{l}\text { Addition of CRP and MPO enhanced the specificity of NT-proBNP } \\
\text { in the screening for LVSD. }\end{array}$ & $\mathrm{Ng}$ et al (67). \\
\hline Hemoglobin, cTnI, BNP & $\begin{array}{l}\text { Anemia is associated with elevated BNP and increased mortality in } \\
\text { HF. Elevation of BNP and cTnI, in patients with HF and anemia has } \\
\text { prognostic value of future events. }\end{array}$ & $\begin{array}{l}\text { Ralli et al } \\
(68) \text {. }\end{array}$ \\
\hline $\begin{array}{l}\text { NT-proBNP, CRP, ST2, } \\
\text { hemoglobin, blood urea } \\
\text { nitrogen (BUN) }\end{array}$ & $\begin{array}{l}\text { Simultaneous measurement of multiple biomarkers in acute dysp- } \\
\text { nea provides additional prognostic information. }\end{array}$ & $\begin{array}{l}\text { Rehman et al } \\
(69) \text {. }\end{array}$ \\
\hline NT-proBNP, galectin-3 & $\begin{array}{l}\text { Combination of NT-proBNP and Gal-3 has shown good prediction } \\
\text { for prognosis in acute HF. }\end{array}$ & $\begin{array}{l}\text { Van Kimme- } \\
\text { nade et al (70). }\end{array}$ \\
\hline $\begin{array}{l}\text { NT-proBNP, MR- } \\
\text { proANP, MR-proADM }\end{array}$ & $\begin{array}{l}\text { Combination of the three biomarkers can provide prognostic infor- } \\
\text { mation regarding cardiovascular and all-cause mortality that could } \\
\text { be used in elderly patients presenting with symptoms suggestive } \\
\text { of heart failure. }\end{array}$ & $\begin{array}{l}\text { Alehagen et al } \\
\text { (71). }\end{array}$ \\
\hline $\begin{array}{l}\text { hs-cTnT, hs-CRP, and } \\
\text { Cys-C along with clinical } \\
\text { risk factors }\end{array}$ & $\begin{array}{l}\text { The score identifies patients with low, intermediate and high risk of } \\
\text { HF. }\end{array}$ & $\begin{array}{l}\text { Eurlings et al } \\
\text { (72). }\end{array}$ \\
\hline sST2, GDF-15, hsTn I & $\begin{array}{l}\text { The multimarker score adds prognostic value to standard risk fac- } \\
\text { tors for predicting death, overall cardiovascular events, and heart } \\
\text { failure. }\end{array}$ & $\begin{array}{l}\text { Wang et al } \\
\text { (73). }\end{array}$ \\
\hline
\end{tabular}

time-of-flight mass spectrometry method of detecting AVP in the urine to probe for doping control purposes. The method has proven high accuracy, robustness and a low limit of detection/quantification (57). C-terminal provasopressin (copeptin) is a more stable propeptide of AVP. Copeptin has been shown to have prognostic value in $\mathrm{HF}$ and was correlated with NYHA functional class (58). Copeptin can be measured using a sandwich immunoluminometric assay with two polyclonal antibodies for 132-164 AA of pre-provasopressin (59).

\section{Biomarkers of myocyte injury in HF}

Myocardial injury has been shown to be more common than previously thought among HF patients. Loss of cardiomyocytes is associated with ventricle remodeling and in general with a worse outcome (60). With the emergence of highly sensitive troponin assays, cardiac troponin T (cTnT) was detected in $92 \%$ of HF patients in comparison to only $10 \%$ in the past (60). Cardiac troponin I (cTnI) at levels $\geq 0.04 \mathrm{ng} / \mathrm{mL}$ is considered an independent predictor of death. Levels of cTnT higher than 0.2 $\mathrm{ng} / \mathrm{mL}$, in patients with $\mathrm{HF}$, were associated with a high hazard ratio for death (60). There are currently six highly sensitive immunoassays commercially available, five for cTnI and one for cTnT (61). Some of them use the " $2+2$ " concept of combining four antibodies: two for capture and two for detection. These antibodies are sensitive to factors that may influence measurement, such as posttranslational modifications (proteolytic degradation, phosphorilation) or complexing with other molecules (heparin, heterophile or human antimouse antibodies). Recently, Moreira et al have tested a novel arti- 
ficial antibody for cTnT that showed high selectivity and sensitivity (62). Moreover, Abad et al have demonstrated that cTnT can be determined in the range of $0.05-1.0 \mathrm{ng} / \mathrm{mL}$ using a cyclo-olefin polymer based microfluidic device for capturing magnetic beads and performing electrochemical detection (63). A detection limit of $2 \mathrm{pg} / \mathrm{mL}$ for cTnI was reached by using nanoparticle-based electrochemiluminescence immunosensor labels in a high sensitive sandwich-type immunoassay (64).

\section{Multimarker approach}

Even though the field of multimarker evaluation is still at the beginning in HF, many studies, as seen in Table IV, have investigated the use of a multimarker strategy in refining diagnosis or risk stratification among patients with HF. Each biomarker is a valuable addition to the multimarker profile, increasing the accuracy of the result (65).

To support this, new multiplex detection methods are being investigated, such as the photonic suspension array for multiplex immunoassay which is a low cost, automated and simultaneous detection method for BNP, cTnI and CRP, used successfully for the investigation of HF patients (74). Park et al also developed a "lab-ona-disc" comprising a multiplex immunoassay for the detection of high sensitivity CRP, cTnI, and NT-proBNP based on a bead-based sandwich type enzyme-linked immunosorbent assay in approximately 20 minutes (75).

\section{Conclusions}

Advances in detection methods bring biomarkers closer to point-of-care testing. Although there are currently many candidate biomarkers for HF, only BNP and NT-proBNP are routinely being used in clinical settings for the diagnosis, prognosis and management of HF. More studies are needed to determine the clinical utility of candidate biomarkers and es- tablish the clinical significance of their values in proximal fluids. Many biomarkers have the potential to be targets of future therapies, this being a starting point for drug design research.

\section{Acknowledgements}

This study has been carried out with the support of the POSDRU No.78702 grant.

\section{Abbreviations}

$\mathrm{HF}=$ heart failure

$\mathrm{MRM}=$ multiple reaction monitoring

ELISA = enzyme-linked immunosorbent assays

$\mathrm{BNP}=$ brain natriuretic peptide

NT-proBNP = amino-terminal fragment

BAS = biotin-avidin system

$\mathrm{Fab}=$ fragment antigen binding

AuNCs = gold nanochains

HRP $=$ horseradish peroxidase

AuNCs-HRP-Ab(2) = gold nanochains and horseradish peroxidase complex labeled secondary antibodies

ANP = A-type natriuretic peptide

$\mathrm{ADM}=$ adrenomedullin

LVEF = left ventricular ejection fraction

MR-proADM = midreagional proADM

MR-proANP = midreagional proANP

$\mathrm{BACH}=$ Biomarkers in Acute Heart Failure trial

$\mathrm{IL}=$ interleukin

GDF-15 = growth differentiation factor 15

TNF- $\alpha=$ tumor necrosis factor

$\mathrm{CRP}=\mathrm{C}$-reactive protein

PTX3 = pentraxin 3

$\mathrm{OPG}=$ osteoprotegerin

MPOs = myeloperoxydases

NYHA = New York Heart Association

MMPs = matrix metalloproteinases

TIMPs $=$ tissue inhibitors of metalloproteinases

TIMP1 = tissue inhibitor of MMP1

GAL-3 = Galectin-3

iTRAQ = isobaric tag for relative and absolute quantitation

ACEI = angiotensin converting enzyme inhibitors

ARBs = aldosterone receptors blockers

ET-1 = Endothelin-1

CT-proET1 = C-terminal pro-endothelin-1

$\mathrm{AVP}=$ Arginine vasopressin 
Copeptin $=$ C-terminal provasopressin

$\mathrm{cTnT}=$ cardiac troponin $\mathrm{T}$

$\mathrm{cTnI}=$ cardiac Troponin I

\section{References}

1. McMurray JJ, Adamopoulos S, Anker SD, Auricchio A, Bohm M, Dickstein K et al. ESC Guidelines for the diagnosis and treatment of acute and chronic heart failure 2012: The Task Force for the Diagnosis and Treatment of Acute and Chronic Heart Failure 2012 of the European Society of Cardiology. Developed in collaboration with the Heart Failure Association (HFA) of the ESC. Eur Heart J 2012;30:1787-1847.

2. Morrow DA, de Lemos JA. Benchmarks for the assessment of novel cardiovascular biomarkers. Circulation 2007;115:949-52.

3. Tang WH, Francis GS, Morrow DA, Newby LK, Cannon CP, Jesse RL et al. National Academy of Clinical Biochemistry laboratory medicine practice guidelines: clinical utilization of cardiac biomarker testing in heart failure. Circulation 2007;116:99-109.

4. Van Kimmenade RRJ, Januzzi JL. Emerging biomarkers in heart failure. Clin Chem 2012;58(1):127-138.

5. Rifai N, Gillette MA, Carr SA. Protein biomarker discovery and validation: the long and uncertain path to clinical utility. Bat Biotechnol 2006;24(8):971-83.

6. Mongra AC, Kaur A. Biosensors activities around the globe. Dig J Nanomat Biostruct 2012;7(4):1457-71.

7. Gaggin HK, Januzzi JL. Biomarkers and diagnostics in heart failure. Biochim Biophys Acta 2013, http://dx.doi.org/10.1016/j.bbadis.2012.12.014

8. Braunwald E. Biomarkers in heart failure. N Engl J Med 2008;358:2148-59

9. McCullough PA, Nowal RM, McCord J, Hollander JE, Herrmann HC, Steg PG et al. B-type natriuretic peptide and clinical judgement in emergency diagnosis of heart failure: analysis from Breathing Not Properly (BNP) Multinational Study. Circulation 2002;106(4):416-22.

10. De Keijzer MH, Perkins S, Motta V, Morelli D, Cristol JP, Dupuy AM et al. Multi-site, multi-country evaluation of analytical and operational performance of a low-mid volume chemiluminescent immunoassay analyzer. Clin Lab 2009;55(9-10):363-70.

11. Prontera C, Emdin M, Zucchelli GC, Ripoli A, Passino C, Clerico A. Analytical performance and diagnostic accuracy of a fully-automated electrochemiluminescent assay for the $\mathrm{N}$-terminal fragment of the pro-peptide of brain natriuretic peptide in patients with cardiomyopathy: comparison with immunoradiometric assay methods for brain natriuretic peptide and atrial natriuretic peptide. Clin Chem Lab Med 2004;42(1):37-44.

12. Yi W, Liang W, Li P, Li S, Zhang Z, Yang M et al. Application of a Fab fragment of monoclonal antibody specific to $\mathrm{N}$-terminal pro-brain natriuretic peptide for the detection based on regeneration-free electrochemical immunosensor. Biotechnol Lett. 2011;33(8):1539-43

13. Liang W, Li Y, Zhang B, Zhang Z, Chen A, Qi D, Yi W, Hu C. A novel microfluidic immunoassay system based on electrochemical immunosensors: an application for the detection of NT-proBNP in whole blood. Biosens Bioelectron. 2012;31(1):480-5

14. Zhuo Y, Yi WJ, Lian WB, Yuan R, Chai YQ, Chen A, Hu CM. Ultrasensitive electrochemical strategy for NTproBNP detection with gold nanochains and horseradish peroxidase complex amplification. Biosens Bioelectron. 2011;26(5):2188-93

15. Fonarow GC, Peacock WF, Phillips CO et al. Admission B-type Natriuretic Peptide Levels and In-Hospital Mortality in Acute Decompensated HF. J Am Coll Cardiol 2007;49:1943-50.

16. Di Somma S, Magrini L, Pittoni V et al. In-hospital percentage BNP reduction is highly predictive for adverse events in patients admitted for acute HF: the Italian RED Study. Crit Care 2010;14:R116.

17. Januzzi JL, Camargo CA, Anwaruddin S, Baggish AL, Chen AA, Krauser DG. The N-terminal Pro-BNP investigation of dyspnea in the emergency department (PRIDE) study. Am J Cardiol 2005;95:948-954.

18. Januzzi JL, van Kimmenade R, Lainchbury J, BayesGenis A, Ordonez-Llanos J, Santalo-Bel M. NT-proBNP testing for diagnosis and short-term prognosis in acute destabilized heart failure: an international pooled analysis of 1256 patients: the International Collaborative of NTproBNP Study. Eur Heart J 2006;3:341-9

19. Moe GW, Howlett J, Januzzi JL et al. N-Terminal Pro-B-Type Natriuretic Peptide Testing Improves the Management of Patients With Suspected Acute HF: Primary Results of the Canadian Prospective Randomized Multicenter IMPROVE-CHF Study. Circulation 2007;115:310310.

20. Maiser A, Mueller C, Nowak R, Peacock WF, Landsberg JW, Ponikwski $\mathrm{P}$ et al. Mid-region pro-hormone markers for diagnosis and prognosis in acute dyspnea: results from the BACH (Biomarkers in Acute Heart Failure) trial. J Am Coll Cardiol 2010;55:2062-76.

21. Morgenthaler NG, Struck J, Alonso C, Bergmann A. Measurement of midregional proadrenomedullin in plasma with an immunoluminometric assay. Clin Chem 2005;51(10):1823-9

22. Missbichler A, Hawa G, Schmal N, Woloszczuk W. Sandwich ELISA for proANP 1-98 facilitates investigation of left ventricular dysfunction. Eur $\mathrm{J}$ Med Res 2001;6(3):105-11.

23. Weinberg EO, Shimpo M, Hurwitz S, Tominaga S, Rouleau JL, Lee RT. Identification of serum soluble ST2 receptor as a novel heart failure biomarker. Circulation 2003;107:721-6.

24. Sanada S, Hakuno D, Higgins LJ, Schreiter ER, McKenzie AN, Lee RT. IL-33 and ST2 comprise a critical biomechanically induced and cardioprotective signaling 
system. J Clin Invest 2007;117:1538-49.

25. Rehman SU, Mueller T, Januzzi JL. Characteristics of novel interleukin family biomarker ST2 in patients with acute heart failure. J Am Coll Cardiol 2008;52:1458-65.

26. Dieplinger B, Januzzi JL Jr, Steinmair M, Gabriel C, Poelz W, Haltmayer M, Mueller T. Analytical and clinical evaluation of a novel high-sensitivity assay for measurement of soluble ST2 in human plasma--the Presage ST2 assay. Clin Chim Acta 2009;409(1-2):33-40.

27. Mueller T, Dieplinger B. The Presage(®) ST2 Assay: analytical considerations and clinical applications for a high-sensitivity assay formeasurement of soluble ST2. Expert Rev Mol Diagn 2013;13(1):13-30.

28. Kempf T, Wollert KC. Growth-differentiation factor15 in heart failure. Heart Fail Clin 2009;5:537-47.

29. Darmanis S, Nong RY, Hammond M, Gu J, Alderborn A, Vänelid J et al. Sensitive plasma protein analysis by microparticle-based proximity ligation assays. Mol Cell Proteomics 2010;9(2):327-35

30. Kempf T, von Haehling S, Peter T, Allhof T, Cicoira $\mathrm{M}$, Doehner W et al. Prognostic utility of growth differentiation factor-15 in patients with chronic HF. J Amer Card 2007;50:1054-60.

31. Stahrenberg R, Edelmann F, Mende M, Kockskämper A, Düngen HD, Lüers C et al. The novel biomarker growth differentiation factor 15 in HF with normal ejection fraction. Eur J Heart Fail 2010;12:1309-16.

32. Seta Y, Shan K, Bozkurt B, Oral H, Mann DL. Basic mechanisms in heart failure: the cytokine hypothesis. $\mathrm{J}$ Card Fail 1996;2:243-9.

33. Vasan RS, Sullivan LM, Roubenoff R, Dinarello CA, Harris T, Benjamin EJ et al. Inflammatory markers and risk of heart failure in elderly subjects without prior myocardial infarction: the Framingham Heart Study. Circulation 2003;107:1486-91.

34. Abe K, Hashimoto Y, Yatsushiro S, Yamamura $S$, Bando M, Hiroshima $Y$ et al. Simultaneous immunoassay analysis of plasma IL- 6 and TNF- $\alpha$ on a microchip. PLoS One 2013;8(1):e53620

35. Tekin HC, Cornaglia M, Gijs MA. Attomolar protein detection using a magnetic bead surface coverage assay. Lab Chip 2013;13(6):1053-9.

36. Brudaşcă I, Cucuianu M. Chronic Stress, Neuroendocrine Disorders and Metabolic Syndrome. Rev Romana Med Lab 2011;19(3):219-226

37. Kalogeropoulos A, Georgiopoulos V, Psaty BM, Rodondi N, Smith AL, Harrison DG et al. Inflammatory markers and incident heart failure risk in older adults: the Health ABC (Health, Aging and Body Composition) study. J Am Coll Cardiol 2010;55:2129-37.

38. Miramontes Espino MV, Romero-Prado MM. Patented Aptamers For C-Reactive Protein Detection: A Review About Their Use In Clinical Diagnostics. Recent Pat DNA Gene Seq. 2013. (Epub ahead of print)

39. Suzuki S, Takeishi Y, Niizeki T, Koyama Y, Kitahara $\mathrm{T}$, Sasaki $\mathrm{T}$ et al. Pentraxin 3, a new marker for vascular inflammation, predicts adverse clinical outcomes in patients with heart failure. Am Heart J 2008;155:75-81.

40. Inoue K, Sugiyama A, Reid PC, Ito Y, Miyauchi $\mathrm{K}$, Mukai S. Establishment of a high sensitivity plasma assay for human pentraxin3 as a marker for unstable angina pectoris. Arterioscler Thromb Vasc Biol 2007;27(1):161-7. 41. Vida-Simiti L, Cristea A. Serum levels of TRAIL OPG and RANKL in patients with severe heart failure. Rev Romana Med Lab 2010;18(4):17-23

42. Tang WH, Brennan ML, Philip K, Tong W, Mann S, Van Lente F, Hazen SL. Plasma myeloperoxidase levels in patients with chronic heart failure. Am J Cardiol 2006;98:796-9.

43. Reichlin T, Socrates T, Egli P, Potocki M, Breidthardt $\mathrm{T}$, Areja $\mathrm{N}$ et al. Use of myeloperoxidase for risk stratification in acute heart failure. Clin Chem 2010;56:944-51.

44. Saravanan L, Juneja S. Immunohistochemistry is a more sensitive marker for the detection of myeloperoxidase in acute myeloid leukemia compared with flow cytometry and cytochemistry. Int J Lab Hematol 2010;32(1):e132-6

45. Buralli S, Dini FL, Ballo P, Conti U, Fontanive P, Duranti $E$ et al. Circulating matrix metalloproteinase- 3 and metalloproteinase-9 and tissue Doppler measures of diastolic dysfunction to risk stratify patients with systolic heart failure. Am J Cardiol 2010;105:853-6.

46. Hawkes SP, Li H, Taniguchi GT. Zymography and reverse zymography for detecting MMPs and TIMPs. Methods Mol Biol 2010;622:257-69.

47. Frantz S, Stork S, Michels K, Eigenthaler M, Ertl G, Bauersachs $\mathbf{J}$ et al. Tissue inhibitor of metalloproteinases levels in patients with chronic heart failure: an independent predictor of mortality. Eur J Heart Fail 2008;10:38895.

48. Lok DJ, Van Der Meer P, de la Porte PW. Prognostic value of galectin-3, a novel marker of fibrosis, in patients with chronic HF: data from the DEAL-HF study. Clin Res Cardiol 2010;99-323-28.

49. Kolla V, Jenö P, Moes S, Lapaire O, Hoesli I, Hahn S. Quantitative proteomic (iTRAQ) analysis of 1 st trimester maternal plasma samples in pregnancies at risk for preeclampsia. J Biomed Biotechnol 2012;2012:305964 50. Park YK, Bold B, Lee WK, Jeon MH, An KH, Jeong SY, Shim YK. d-(+)-Galactose-Conjugated Single-Walled Carbon Nanotubes as New Chemical Probes for Electrochemical Biosensors for the Cancer Marker Galectin-3. Int J Mol Sci 2011;12(5):2946-57.

51. Săvoiu G, Cristescu C, Şerban C, Noveanu L, Borza $\mathrm{C}$, Dehelean C, et al. Endothelin-1 plasma concentration in patients with essential hypertension, atherogenic dyslipidemia and coronary artery disease. Rev Romana Med Lab 2010;18(4):25-30

52. Kemp CD, Conte JV. The pathophysiology of heart failure. Cardiovasc Pathol 2012;21(5):365-71.

53. Francis GS. Neurohormonal control of heart failure. Cleve Clin J Med 2011;78:S75-9. 
54. Laricchia-Robbio L, Moscato S, Guidi A, Viganò S, Rovero P, Revoltella RP. Detection and epitope mapping of immunoreactive human endothelin-1 using ELISA and a surface plasmon resonance-based biosensor. Biosens Bioelectron 1997;12(8):765-78.

55. Sabatine MS, Morrow DA, de Lemos JA, Omland T, Sloan S, Jarolim P et al. Evaluation of multiple markers of cardiovascular stress for risk prediction and guiding medical therapy in patients with stable coronary disease. Circulation 2012;125:233-40.

56. Papassotiriou J, Morgenthaler NG, Struck J, Alonso $\mathrm{C}$, Bergmann A. Immunoluminometric assay for measurement of the C-terminal endothelin-1 precursor fragment in human plasma. Clin Chem 2006;52(6):1144-51.

57. Thomas A, Solymos E, Schänzer W, Baume N, Saugy M, Dellanna F, Thevis M. Determination of Vasopressin and Desmopressin in urine by means of liquid chromatography coupled to quadrupole time-of-flight mass spectrometry for doping control purposes. Anal Chim Acta 2011;707(1-2):107-13.

58. Neuhold S, Huelsmann M, Strunk G, Stoiser B, Struck J, Morgenthaler NG et al. Comparison of copeptin, B-type natriuretic peptide, and amino-terminal pro-B-type natriuretic peptide in patients with chronic heart failure: prediction of death at different stages of disease. J Am Coll Cardiol 2008;52:266-72.

59. Morgenthaler NG, Struck J, Alonso C, Bergmann A. Assay for the measurement of copeptin, a stable peptide derived from the precursor of vasopressin. Clin Chem 2006;52(1):112-9.

60. Latini R, Masson S, Anand IS, Missov E, Carlson M, Vago $T$ et al. Prognostic value of very low plasma concentrations of troponin $\mathrm{T}$ in patients with stable chronic heart failure. Circulation 2007;116:1242-9.

61. Apple FS, Collinson PO. Analytical Characteristics of High-Sensitivity Cardiac Troponin Assays. Clin Chem 2012;58:54-61

62. Moreira FT, Dutra RA, Noronha JP, Cunha AL, Sales MG. Artificial antibodies for troponin T by its imprinting on the surface of multiwalled carbon nanotubes: its use as sensory surfaces. Biosens Bioelectron 2011;28(1):243-50. 63. Abad L, Javier del Campo F, Muñoz FX, Fernández LJ, Calavia D, Colom G et al. Design and fabrication of a COP-based microfluidic chip: chronoamperometric detection of Troponin T. Electrophoresis 2012;33(21):3187-94. 64. Shen W, Tian D, Cui H, Yang D, Bian Z. Nanoparticle-based electrochemiluminescence immunosensor with enhanced sensitivity for cardiac troponin I using $\mathrm{N}$ (aminobutyl)-N-(ethylisoluminol)-functionalized gold nanoparticles as labels. Biosens Bioelec- tron $2011 ; 27(1): 18-24$

65. Allen LA, Felker MG. Multi-marker strategies in heart failure: clinical and statistical approaches. Heart Fail Rev 2010;15:343-9.

66. Zethelius B, Berglund L, Sundström J, Ingelsson E, Basu S, Larsson A et al . Use of multiple biomarkers to improve the prediction of death from cardiovascular causes. N Engl J Med 2008;358:2107-16.

67. Ng LL, Pathik B, Loke IW, Squire IB, Davies JE. Myeloperoxidase and C-reactive protein augment the specificity of B-type natriuretic peptide in community screening for systolic heart failure. Am Heart J 2006;152:94-101.

68. Ralli S, Horwich TB, Fonarow GC. Relationship between anemia, cardiac troponin I and B-type natriuretic peptide levels and mortality in patients with advanced heart failure. Am Heart J 2005;150:1220-1227.

69. Rehman SU, Martinez-Rumayor A, Mueller T, Januzzi JL. Independent and incremental prognostic value of multimarker testing in acute dyspnea: results from the ProBNP Investigation of Dyspnea in the Emergency Department (PRIDE) study. Clin Chim Acta 2008;392:41-45. 70. Van Kimmenade RR, Januzzi JL, Ellinor PT, Sharma UC, Bakker JA, Low AF et al. Utility of amino-terminal pro-brain natriuretic peptide, galectin-3, and apelin for the evaluation of patients with acute heart failure. J Am Coll Cardiol 2006;48:1217-24.

71. Alehagen U, Dahlström U, Rehfeld JF, Goetze JP. Pro-A-type natriuretic peptide, proadrenomedullin, and Nterminal pro-B-type natriuretic peptide used in a multimarker strategy in primary health care in risk assessment of patients with symptoms of heart failure. J Card Fail 2013;19(1):31-9.

72. Eurlings LW, Sanders-van Wijk S, van Kimmenade R, Osinski A, van Helmond L, Vallinga $M$ et al. Multimarker strategy for short-term risk assessment in patients with dyspnea in the emergency department: the MARKED (Multi mARKer Emergency Dyspnea)-risk score. J Am Coll Cardiol 2012;60(17):1668-77.

73. Wang TJ, Wollert KC, Larson MG, Coglianese E, McCabe EL, Cheng S et al. Prognostic utility of novel biomarkers of cardiovascular stress: the Framingham Heart Study. Circulation 2012;126(13):1596-604.

74. Lu W, Fu C, Chen Y, Lu J, Yao Y, Shen C, Gu Z. Multiplex detection of B-type natriuretic peptide, cardiac troponin I and C-reactive protein with photonic suspension array. PLoS One 2012;7(7):e41448

75. Park J, Sunkara V, Kim TH, Hwang H, Cho YK. Lab-on-a-disc for fully integrated multiplex immunoassays. Anal Chem 2012; 84(5):2133-40. 